\title{
The influence of capital structure on the value of public companies in chemical industry
}

\author{
Anna Bitjukova ${ }^{1}$, Elizaveta Markovskaya ${ }^{2 *}$, Vladimir Bruz ${ }^{3}$, and Sergey Vititnev ${ }^{3}$ \\ ${ }^{1}$ LLC "Qbex Logistics",187021, Shosseynaya str., bld. 2G, Leningrad region, Fedorovskoe, Russia \\ ${ }^{2}$ National Research University Higher School of Economics, 16 Soyuza Pechatnikov Street, \\ St Petersburg, 190121 \\ ${ }^{3}$ Moscow Region State University, 105005, Radio str, 10A, Moscow, Russia
}

\begin{abstract}
The study is about the relation between the financial leverage and the value of a firm in the chemical industry. Financial stability (low level of growth and financial health) is considered as a factor that can influence the relation. The panel data analysis of the sample of public chemical companies is used. Instrumental variables are used to avoid endogenity problem of the leverage in the model. We find that the relation between the financial leverage and the value is positive. We show that the big amounts of debt past the optimum level influence company's market value negatively. We also find that financial stability influences the relation between the leverage and the value only partly. Financial health strengthens the relation while growth has little or no influence on the relation. Testing for the change of influence patterns before and after financial crisis of 2008 gives significant difference only in relation between the value and the square financial leverage. In the first part of this work the existing body of literature on the relation between the financial leverage and the value of a company will be studied and hypotheses will be formulated. The second part will be dedicated to methodology of the study. The third part will contain the description of the data and the results of econometric analysis.
\end{abstract}

\section{Introduction}

One of the main indicators for any company is its value. Enhancing it is often considered one of the most important aims of any business. So it is vital to understand and manage factors that affect it, especially the financial leverage. The known relation between company's value and financial leverage can show and aid firms' managers the best financing strategy that will increase the value of the firm in the eyes of potential and existing investors.

There are existing lot of different researches dedicated to this topic beginning from the introduction of it by researchers Modigliani and Miller (1958) [1]. However, none of the research works ever came to a common conclusion about the relation between the financial

\footnotetext{
* Corresponding author: markovskaya@ yandex.ru
} 
leverage and the value of a company. Many of the works have tried to use factors that may aid to clarify the differences in this relation. In this work several such factors are introduced. Firstly, as some studies reported the presence of an industry specific effect only one industry - chemical - is looked at. Companies in chemical industry depend a lot on research and development and intangible assets (which have a big share in total assets). This increases risks of bankruptcy for firms making financial leverage rather important in eyes of investors in chemical companies. Secondly, another factor that might help to make the relation more clear- the square term of financial leverage - is introduced to the analysis. Its usage will show whether there is a non-linear relationship between the financial leverage and the value of a company. Thirdly, financial stability is considered as an impact factor on the linear relation between the capital structure and the value.

In the first part of this work the existing body of literature on the relation between the financial leverage and the value of a company will be studied and hypotheses will be formulated. The second part will be dedicated to methodology of the study. The third part will contain the description of the data and the results of econometric analysis.

\section{Literature review}

The goal of this literature review is to review the existing body of academic works about the influence of the company's financial leverage on its value. However, first of all, we will examine the two theories of financing. Secondly, we will study the articles about the actual relation between the chosen capital structure and the company's value as well as the factors that may have an influence over it. Lastly, we will briefly look at the most popular methods to measure the company's value.

The study of Modigliani and Miller (1958) can be viewed as the fundamental work in the area of investing and especially financing decisions of the firm. They claimed that the introducing of certain assumptions (the absence of taxes,effective capital market, agency costs and the costs of bankruptcy, asymmetric information), ensure that financing and investment decisions are made independently from each other. Yet in the real market these assumptions are often not met with. Thus, after the work of Modigliani and Miller the researches followed, which removed one or several of the assumptions stated above [2].

One part of those works is associated with the existence of taxes (and accordingly with the presence of tax shields), and the existence of bankruptcy costs.Other researchers explain these decisions also by information asymmetry that exists on financial market. Using these parameters (basically removing some of Modigliani and Miller assumptions) the researchers developed two theories, which explained the choice of the capital structure by a company: the trade-off theory and the pecking order theory.

The pecking order theory gets rid of the assumption that the information asymmetry and transaction costs are absent. Mayers and Majluf (1984) demonstrate that firms prefer internal financing to external financing and use their retained earnings and reserves. When in need to use the external financing firms would rather issue debt, than shares. This happens because when there is an information asymmetry the stock price decreases when of new equity is released and remains at the same level when the new debt is released. In addition, the operating costs for the issuing of new shares are higher than the costs for the issuing of debt and using of internal financing [3,4].

The trade-off theory, just the same, discards the proposition of the absence of bankruptcy costs and taxes. Kraus and Litzenberger (1973) argue that firms look for the optimal level of debt by focusing on the costs of not paying of debt and the amount of taxes [5]. The tax rate is vital, in case of the interest payments being not taxed. Then the growth of the volume of debt in the capital structure decreases taxable income and therefore rises the after tax profit. Yet, as the debt needs to be paid completely in a certain period, the firm 
might be threatened by bankruptcy if there are not enough of the necessary means to make payments. This will cause the fall of the firm value (if the company is able to continue its activities) or the bearing of large costs connected with the closure of the firm. Accordingly, companies choose the level of debt that will balance the gain from the tax shield and the loss from the bankruptcy costs, that is, the level which maximizes firm value.

A firm might follow the different strategies to select its capital structure because this financial decision is quite significant: financial leverage may influence different aspects of business such as company's profits, performance, risk of bankruptcy and most prominently its market value. The whole body of previous literature exists on the question of the influence which the financial leverage has on the value of companies. However, there is not a single opinion about the sign of the relation or factors that are vital to defining it. In table 1 there is an overview of different works about this question.

Table 1. Articles on relation between financial leverage and company's value.

\begin{tabular}{|c|c|c|c|}
\hline Article & \multicolumn{2}{|c|}{$\begin{array}{l}\text { Relationship between financial leverage and } \\
\text { firm's value } \\
\end{array}$} & $\begin{array}{l}\text { Country of analyzed } \\
\text { companies }\end{array}$ \\
\hline \multirow{2}{*}{$\begin{array}{l}\text { McConnel, } \\
\text { Servaes, } 1995\end{array}$} & Low-growth firms & $\begin{array}{l}\text { High-growth } \\
\text { firms }\end{array}$ & \multirow{2}{*}{ USA } \\
\hline & positive correlation & $\begin{array}{l}\text { negative } \\
\text { correlation }\end{array}$ & \\
\hline \multirow{2}{*}{$\begin{array}{l}\text { Aggarwal, Zhao, } \\
2007\end{array}$} & Low-growth firms & $\begin{array}{l}\text { High-growth } \\
\text { firms }\end{array}$ & \multirow{2}{*}{ USA } \\
\hline & negative correlation & $\begin{array}{l}\text { negative } \\
\text { correlation }\end{array}$ & \\
\hline \multirow{2}{*}{$\begin{array}{l}\text { De Andres Alonso, } \\
\text { Iturriaga, Sanz, } \\
\quad 2005\end{array}$} & No growth opportunities & $\begin{array}{c}\text { Growth } \\
\text { opportunities }\end{array}$ & \multirow{2}{*}{ Spain } \\
\hline & positive correlation & $\begin{array}{l}\text { negative } \\
\text { correlation }\end{array}$ & \\
\hline $\begin{array}{l}\text { Cheng, Tzeng, } \\
2011\end{array}$ & \multicolumn{2}{|c|}{$\begin{array}{l}\text { positive (stronger effect if firm is financially } \\
\text { healthy); only till optimal level of leverage }\end{array}$} & China \\
\hline $\begin{array}{l}\text { Adenugba et. al., } \\
2016\end{array}$ & \multicolumn{2}{|c|}{$\begin{array}{l}\text { curvilinear: positive before optimal level and } \\
\text { negative after }\end{array}$} & Nigeria \\
\hline $\begin{array}{l}\text { Farooq, Masood, } \\
2016\end{array}$ & \multicolumn{2}{|c|}{ positive correlation } & Pakistan \\
\hline Khan, 2012 & \multicolumn{2}{|c|}{ negative correlation } & Pakistan \\
\hline $\begin{array}{c}\text { Soumadi, } \\
\text { Hayajneh, } 2012\end{array}$ & \multicolumn{2}{|c|}{ negative correlation } & Jordan \\
\hline Fosu et. al., 2016 & \multicolumn{2}{|c|}{$\begin{array}{l}\text { negative correlation (weaker for information } \\
\text { asymmetricfirms) }\end{array}$} & UK \\
\hline Cai, Zhang, 2011 & \multicolumn{2}{|c|}{$\begin{array}{l}\text { negativecorrelation (stronger for firms with a } \\
\text { greater likelihood of debt overhang) }\end{array}$} & USA \\
\hline $\begin{array}{l}\text { Ishari, Abeyrathna, } \\
2016\end{array}$ & \multicolumn{2}{|c|}{ weak negative correlation } & Shri-Lanka \\
\hline \multirow{2}{*}{ Barakat, 2014} & \multicolumn{2}{|c|}{ no correlation } & Saudi Arabia \\
\hline & \multicolumn{2}{|c|}{$\begin{array}{l}\text { Relationship between financial leverage and } \\
\text { firm's performance }\end{array}$} & \\
\hline Fosu, 2013 & \multicolumn{2}{|c|}{ positive correlation } & South Africa \\
\hline Weil, 2008 & \multicolumn{2}{|c|}{$\begin{array}{c}\text { positive correlation - Germany, France, } \\
\text { Belgium, Norway and Spain } \\
\text { negative correlation - Italy } \\
\text { no correlation - Portugal }\end{array}$} & $\begin{array}{l}\text { Germany, France, Italy, } \\
\text { Belgium, Portugal, } \\
\text { Spain, Norway }\end{array}$ \\
\hline
\end{tabular}

Source: authors' review

Using the sample of the USA public non-financial companies McConnel and Servaes (1995) found that for low growth firms capital structure and firm's value are positively 
correlated while for high growth firms they are negatively correlated [6]. However, Aggarwal and Zhao (2007) used a similar sample little more than a decade later and discovered that companies have negative relation between the financial leverage and the companies' value regardless of their growth levels. The authors proclaimed to have used more accurate leverages for the research since the control for the industry differences was brought into methodology. Yet, the difference of the results of two papers might also have been caused by the American market time differences. Much like McConnel and Servaes (1995) Spanish authors (De Andres Alonso, Iturriaga, Sanz, 2005) showed that the influence of the capital structure on company's value depends on the company's growth opportunities: positive for firms without growth opportunities and negative for firms with them[6,7,8] .

Cheng and Tzeng (2011) using the sample of firms listed on Taiwan Stock Exchange showed that capital structure correlates positively with company's value and that this relation becomes stronger for the financially healthier firms[9]. However, such effect takes place only before a company reaches its optimal capital structure. The similar outcome was found for Nigerian companies by Adenugba, Ige and Kesinro (2016): the general relation between the financial leverage and the company's value was positive[10]. Yet for some firms of the sample the company's value, at first, increased as the leverage grew but after the value started to fall while the leverage was still growing.

Similarly the positive relation between capital structure and company's value was established for the Pakistan public firms in the cement sector by Farooq and Masood (2016), though the researchers did not try to use any parameter that could influence the relation between the studied values[11]. One more researcher (Khan, 2012) of the public firms in Pakistan, in a different - engineering - sector detected the negative relation between the capital structure and the company's value [12] These two results indicate that the sector of economy may be an important parameter for defining the relation just the same as the more performance-related factors like financial health, growth or market competition.

Soumadi and Hayajneh (2012) also revealed that the capital structure and the company's value are negatively correlated using the sample of the Jordan firms listed on Amman Stock Exchange[13]. The researchers also tried to find difference in the relation for firms with different levels of financial leverage and growth rates. However, it was showed that companies with both low and high growth had the similar relation between the capital structure and company's value. Just the same companies with both low and high financial leverage had no statistically significant differences in the researched relations.

Other researchers (Fosu et al., 2016) also detected that the correlation between capital structure and the company's value was negative for the public firms in UK [14,15]. Similar to Soumadi and Hayajneh (2012) these authors checked whether the factor - information asymmetry - affected this relationship [16]. They found that the more a company had information asymmetry the less company's value was influenced by financial leverage.Cai and Zhang (2011) researched the sample of companies in the USA[17]. They discovered that a rise in the financial leverage affected company's stock prices negatively. Moreover this effect was amplified if companies had a problem of debt overhang.

However, not all researches revealed the presence of the correlation between the financial leverage and the company's value. On the sample of Shri-Lanka companies Ishari and Abeyrathna (2016) displayed that the relation was weak (even though negative) [18]. At the same time for the Saudi Arabia firms Barakat (2014) detected no relation between the financial leverage and the company's value at all [19].

In another article Fosu(2013) studied the impact of the financial leverage on the company's performance measured by return on assets[20]. The research was based on sample of the South African companies. The impact was discovered to be positive and enhanced by presence of product market competition. Weil (2008) also looked at the 
relation between the financial leverage and the company's performance, but on the sample of European companies[Ошибка! Источник ссылки не найден.]. He discovered that the relation is positive in Belgium, France, Germany,Spain and Norway, it is negative in Italy and in Portugal such relation does not exist. This shows that even with use one methodology and one time period the correlation between the capital structure and the company's value might be different.

Financial stability shows the ability of a company to constantly meet long term and short term financial obligations and to continue to grow steadily. That includes the capability to pay for the obligations to all the stakeholders of a company. There is a number of factors that can be applied for measuring of financial stability. (Ježovita, 2015) [22]In this work the financial stabilityof a company consists of two factors: company's low growth and its financial health.

First indicator of financial stability - growth level - influences the relationship between the financial leverage and the value of firm mainly through the problems of not optimal investment (Aggarwal, Zhao, 2007) [23].

High levels of growth of a company might be a cause (as a source of spare financial resources) or even an indicator of an overinvestment problem in a company. According to Jensen(1986) and Stulz(1990)if the company has excess free cash flow and the simultaneous absence of profitable investment projects, managers will still invest in projects that are unprofitable for the company instead of paying excess cash as dividends [24]. This unjustified increase in the size of the company is beneficial to managers, as it increases their monetary reward and raises their prestige. Increasing the leverage can help owners to mitigate this problem as managers will not have so many resources to invest in unprofitable projects. Thus, the bigger will be the leverage the higher will be the value of a firm.

At the same time, for a high growth firm that has resources and ways to develop still further an underinvestment problem might exist. Myers (1977) argues that in the presence of a large amount of debt, the company's profitable investment projects generate revenue that goes primarily to its creditors $[25,26]$. Only the residual part of the profits remains for the owners.At the same time the costs of the project fall just on the owners. In this case, managers act in the interests of the owners and choose investment projects that are not only profitable, but also bring a very high expected income that covers the nominal amount of debt. Thus, bigger leverage might cause firm to have lower value because of missed growth opportunities.

Briefly, financing by debt can raise the value of a firm because it gives a tax advantage and it helps to moderate the over-investment problem boosted by managers .On the other hand, debt can lower value as well because of the bankruptcy costs and it may aggravate the under-investment problem especially for high growth firms.

The second indicator - financial health - also influences the relationship between the capital structure and the value of a company. Companies with different financial qualities might incur different bankruptcy costs if they use debt financing. Basically, firms which are more financially healthy may have lower bankruptcy costs than those which have worse financial quality. Thus, it can be supposed that firms that are more financially healthy might have stronger positive effect on firm values than firms that are less financially healthy (Cheng, Tzeng, 2011) [27,28].

The financial health of a firm can be measured as a likelihood of its bankruptcy. Beaver (1966) was the first one to demonstrate that financial ratios can be useful in the forecast of a firm failure [29]. Since then numerous financial distress and bankruptcy prediction models have been developed (Altman, 1968; Ohlson, 1980; Zmijewski, 1984) with the use of various modeling techniques [30,31,32]. Altman Z-score model remains the most popular. 
It is probably due to the fact that it is easy to use and still gives reliable forecast to the likelihood of a firm's failure in the next two years (Altman, 2000) [34].

Altman Z-score may be used to forecast the probability of a company going into bankruptcy during the next two years that is company's financial unhealthiness.

Altman's Z-score (1968)is calculated by the following formula:

$Z=1.2 X_{1}+1.4 X_{2}+3.3 X_{3}+0.6 X_{4}+1.0 X_{5}$

There $X_{I}$ is the share of liquid assets in all assets of the company. It shows the liquidity characteristic of a company: the bigger the working capital the smaller risk of insolvency. $X_{2}$ is the share of retained earnings in all assets of the company. It is a measure of accumulated profits of company which also indirectly implies the age of a firm: the younger a firm is and the less accumulated capital it has the bigger is the risk of bankruptcy. $X_{3}$ is the share of operating earnings in all assets of the company. It measures true productivity of a company without influence of any shields. $X_{4}$ is the ratio between the market value of equity and the book value of liabilities which gives market dimension. And $X_{5}$ is the asset turnover which shows assets' sales generating ability. If Altman Z-score is more than 2.99, a company is considered financially healthy. If it is less than 2.99 , a company is considered not financially healthy.

In order to study the impact that financial leverage has on company's value the value itself needs to be found.

The first and most easily obtained measure of a company's value is its net worth or book value of its assets. However, it might be not very accurate due to different accounting principles used across the world. Moreover, it does not show the true value of company in eyes of investors.

The measuring of a company's value based on its stock prices is another and, perhaps, the most popular way to find public company value. It is often done through the use of Tobin's q which is approximated according to the model of Chung and Pruitt (1994). As stated by them it can be measured as the company's market value of equity and the book value of debt divided by the book value of assets. Yet this method can be used only for publicly traded companies.

Another method is to capitalize the company's future performance. This measure is possible for any company. However, for the method to work accurately the future conditions need to be known with at least some degree of certainty. Yet another measure is the deductive usage of human judgment. With this measure, companies are rated into a psychometric scale. Then the results are transformed to monetary values by formula. The main problem of the method is that it requires the subjective judgment(Thavikulwat, 2004)[35].

Thus, the easiest method which is applicable for this work is the using of Tobin's q.

The existing body of literature reveals that the capital structure can be chosen by the companiesin accordance with different strategies (for example, assessing the information asymmetry between potential investors and managers or choosing between tax advantages of debt and its bankruptcy disadvantages). But however selected, the financial leverage influences such vital indicator as company's value. Most researchers agree that this relation exists in real world. However, they cannot come to a united opinion as to what kind exactly (positive or negative) is the correlation between the financial leverage and the company's value.

It is worthy of mentioning that some researchers attempted to find factors that may cause the relation to be diverse for different firms. However, in many cases the sign of the correlation stays the same. Though, it may become weaker or stronger if firms answer some condition about the chosen factor. At the same time we can see cases when different studies of companies in one country but in different industries yield opposite results. This shows 
that industry may have a significant impact on the influence of the financial leverage on the company's value. Moreover, some studies revealed that though the financial leverage of a company continuously increased or decreased, its value first grew and then fell or vice versa indicating non-linear relationship.

\section{Hypotheses}

Firstly, we want to point out that only companies in chemical industry will be considered in this research. Financial performance of companies differsthroughoutthe different industries. The researchers find that there isa distinct variation in the capital structure of companies across the various industries (for example, Fries et al., 1997; Miao, 2005). Thus, it is worthwhile to look at the influence of the capital structure on the value of a company controlling the industry effects (Aggarwal, Zhao, 2007) [36].

The chemical industry was chosen because it is different frommany other industries. The research and development along with the efficiency of labor and fixed assets are critical for the profitability and consequently for the value of companies (Voulgaris, Lemonakis, 2014).Besides, the intangible assets play an important role in explaining of variations in the company value (Gleason, Klock, 2006) [37,38]. Such a big dependence on research and development and intangible assets (and their big share in total assets) increases risks of bankruptcy for firms in chemical industry. Thus, financial leverage is very important in eyes of investors, especially when firm is not financially stable. Therefore in chemical industry impact of financial stability on the correlation between capital structure and value should be rather distinctive.

Based on the literature research above four hypotheses can be developed.

H1. In chemical industry the financial leverage positively influences the firm's value.

As stated by most of articles in the literature review the capital structure has either negative or positive influence on the company's value. It holds true not just for the companies of a certain country but also for the companies of a specific industry (Khan, 2012; Farooq and Masood, 2016) [39,40].

The positive relation between the financial leverage and the value can be the consequence of tax advantages given by the debt (Modigliani and Miller, 1963) [41,42]. Tax shields enablecompanies to save resources for future investments or dividends which gives rise tothe company value. Also the positive influence of leverage can be explained by the discipline of managers provided by the presence of debt. The large amounts of debt help to mitigate the overinvestment problem resulting from empire building motivesof company managers (Jensen, 1986; Stulz, 1990) [43,44]. Moreover, the positive relation of the leverage and the value might be a resultof banks' control over the loans they provide: they often give financing only for investing in the profitable projects (Soumadi, Hayajneh, 2012) [45].

H2. In chemical industry the square term of the financial leverage negatively influences the firm's value, e.g. relationship between the financial leverage and firm value is nonlinear.

The capital structure at different levels may have different impact on the company value. Big amounts of debt might stimulate the problems connected to suboptimal investment strategies (La Rocca, Gerace, 2008), lower the advantages given by tax shield (Abor, 2005) or just make a firm less stable in eyes of investors [46,47]. All of these impacts lessen the value of company for shareholders.

The trade-off financing theory likewise implies the presence of an optimal level of the financial leverage (Kraus, Litzenberger, 1973) [48]. It means that the value of a firm will increase as the financial leverage grows to that optimum level and will decrease as the 
leverage continues to grow past the optimum. That results in the negative influence of the square term of the financial leverage on the company value.

Thus, while the low levels of the financial leverage have positive influence on the value of a company, the bigger levels have a negative influence. This nonlinear influence of the leverage causes the company value to depend on the square term of the leverage along with the simple leverage.

H3. For the low growth firms the influence of the capital structure on the value is stronger than for the high growth firms.

In some previous works level of growth of the company influenced the relationship between the capital structure and the value significantly. In the sample used by McConnel and Servaes (1995) the influence was different in sign depending on the level of growth $[49,50]$. For the low growth firms there was a strong positive correlation between the leverage and the value of a company.

The low growth firms are less volatile and more predictable.by their various financial indicators. Stock prices of low growth firms are often influenced by indicators that are the most visible to investors such as earnings per share (Chang, et. al, 2008), dividends (Esteve, et. al, 2017),capital structure [51,52]. So for the low growth companies investors are more likely to follow capital structure to evaluate a company than for the high growth firms.

H4. The financial health makes the influence of the capital structure on the value stronger.

Similar results were received by Cheng and Tzeng (2011) though only for China and for the companies in many industries. Yet this might be the same for the chemical companies in the whole world $[53,54]$.

The more financially healthy the firm is the better debt and equity holders think about it. Thus, good financial health provides company with lower costs of capital and the use of external financing increases company's value more than it would for financially unhealthy firms with higher costs of capital. Besides, smaller costs of external financing make it easier for a firm to change its capital structure according to its needs. And the investors will follow this easily changed indicator more closely.

\section{Methodology}

Regression analysis of panel data is used as the main tool for testing hypotheses. We estimate regressions using ordinary least squares method. Yet the firm financial leverage might be correlated with the explanatory variables, resulting in inconsistent and biased estimates (Fosu, 2016) [54]. Thus, we estimate the regressions using panel fixed effects estimation, and pooled ordinary least squares estimations with instrumental variables for financial leverage to avoid endogenity problem. We base the results on the standard errors that are robust to heteroscedasticity.

\section{Models specification}

For the testing of the first hypothesis that the financial leverage positively influences the firm value we use the panel regression (1):

$$
Q_{i, t}=\beta_{0}+\beta_{1} \text { FLev }_{i, t}+\beta_{2} \text { Size }_{i, t}+\beta_{3} \text { Tang }_{i, t}+\beta_{4} \text { CapEx }_{i, t}+\beta_{5} \text { Prof }_{i, t}
$$

Here the coefficient $\beta_{1}$ indicates the influence of the leverage on the firm value.

To test the second hypothesis that the square term of the financial leverage negatively influences the value of a firm we add the variable of the square of the financial leverage and estimate the panel regression (2): 


$$
Q_{i, t}=\beta_{0}+\beta_{1} \text { FLev }_{i, t}+\beta_{2} \text { SqFinLev }_{i, t}+\beta_{3} \text { Size }_{i, t}+\beta_{4} \operatorname{Tang}_{i, t}+\beta_{5} \operatorname{CapEx}_{i, t}+\beta_{6} \text { Prof }_{i, t}
$$

Here the relation between the square tern of the financial leverage and the firm's value is studied. It is represented by the coefficient $\beta_{2}$.

For the testing of the third hypothesis a variable representing growth of a firm is introduced. It is added to the regression (1) separately and in interaction with the financial leverage. We estimate the following panel regression (3):

$Q_{i, t}=\beta_{0}+\beta_{1}$ FLev $_{i, t}+\beta_{2} G \eta_{i, t}+\beta_{3}$ FLev $_{i, t} G_{i, t}+\beta_{4} \operatorname{Size}_{i, t}+\beta_{5}$ Tang $_{i, t}+\beta_{6} \operatorname{CapEx}_{i, t}+$ $\beta_{7}$ Prof $_{i, t}$

Here level of growth is calculated based on the changes in revenue:

$$
G r_{i, t}=\frac{\text { sales }_{i, t}}{\text { sales }_{i, t-1}}
$$

Where Sales $_{t}$ is the amount of sales of a firm in a current year and Sales t-I $_{t}$ is the amount of sales of a firm in a previous year.

To check how the relation between the leverage and the value is actually affected by growth level we obtain the marginal effects of the leverage on the value depending on the growth level:

$$
\frac{\partial(Q)}{\partial(\text { FLEV })}=\beta_{1}+\beta_{3} G \eta_{l, t}
$$

Where parameter $\beta_{3}$ shows the effects of the growth level on the relationship.

To test the fourth hypothesis a variable showing financial health of a company Altman's Z-score dummies are added to the regression (1) also both separately and in interaction with the financial leverage. The following panel regression (6) is estimated:

$Q_{i, t}=\beta_{0}+\beta_{1} F_{L e v_{i, t}}+\beta_{2} Z g_{i, t}+\beta_{3} Z s_{i, t}+\beta_{4} F_{L e v_{i, t}} Z g_{i, t}+\beta_{5} F L e v_{i, t} Z s_{i, t}+\beta_{6} \operatorname{Size}_{i, t}+$ $\beta_{7}$ Tang $_{i, t}+\beta_{8}$ CapEx $_{i, t}+\beta_{9}$ Prof $_{i, t}$

Here Altman's Z-score is calculated according to Altman's methodology (1968):

$$
Z_{i, t}=1.2 X_{1 i, t}+1.4 X_{2 i, t}+3.3 X_{3 i, t}+0.6 X_{4 i, t}+1.0 X_{5 i, t}
$$

Coefficients $X_{1}, X_{2}, X_{3}, X_{4}$ and $X_{5}$ are the following financial indicators of a firm.

$$
X_{1 i, t}=\frac{W c_{i, t}}{\tau o t A s_{i, t}}
$$

Where $W C$ is the total amount of working capital of a company in a year and TotAs is the total amount of assets of a company in a year.

$$
X_{2 i_{z}, t}=\frac{R \bar{E}_{i, t}}{\tau \circ s_{i, t}}
$$

Where $R E$ is the total amount of retained earnings of a company in a year and TotAs is the total amount of assets of a company in a year.

$$
X_{3 \mathrm{i}, t}=\frac{E B I T_{i, t}}{\tau o t A s_{i, t}}
$$

Where EBIT is the total amount of earnings before interest and taxes of a company in a year and TotAs is the total amount of assets of a company in a year. 


$$
X_{4 i, t}=\frac{M V E q_{i, t}}{T o t z i a b_{i, t}}
$$

Where $M V E q$ is the total market value of equity of a company and TotLiab is the total amount of liabilities of a company in a year.

$$
X_{5 i, t}=\frac{\operatorname{sales}_{i, t}}{\operatorname{TotAs}_{i, t}}
$$

Where Sales is the total amount of sales of a company in a year and TotAs is the total amount of assets of a company in a year.

If from formula (7) $Z_{i, t}$ is more than 2.99 than a company for a firm-year observation is considered financially healthy (in safe zone). If it is less than 2.99 but more than $1.81 \mathrm{a}$ company is considered not very healthy (in grey zone). If it is less than 1.81 a company is considered not financially healthy (in distress one). Dummy variables $Z g$ and $Z s$ are made for companies being in grey zone and safe zone respectively. If both dummy variables are zero than a company for the certain year is considered to be in distress zone.

To see how the relation between the leverage and the value is affected by financial health we measure the marginal effects of the leverage on the value depending on the financial health:

$$
\frac{\partial(Q)}{\partial(\text { FLev })}=\beta_{1}+\beta_{4} Z g_{i, t}+\beta_{5} Z s_{i, t}
$$

Where parameter $\beta 4$ and $\beta 5$ show the effects of the financial health on the relationship.

Dependent variable

Tobin's q $(Q)$ is used as the measure of firm's value. It is calculated as the market value of equity and the book value of debt divided by the book value of assets of a company (Chung, Pruitt, 1994):

$$
Q_{i, t}=\frac{M V E q_{i, t}+\operatorname{TotLlav}_{i, t}}{\tau o t A s_{i, s}}
$$

Here $M V E q$ is the market value of equity of a firm, TotLiab is the amount of liabilities of a firm and TotAs is the amount of assets of a firm in a year.

Independent variables

The two main independent variables are the financial leverage of a firm (FinLev) and its square term (SqFinLev). The financial leverage is computed as the proportion of total debt (both current liabilities and long term debt) in a firm's total assets in a year:

$$
\text { FinLev } v_{i, t}=\frac{L T D e o t_{i, t}+C L_{i, t}}{T \text { ot } A s_{i, t}}
$$

HereLTDebt is the amount of long term debt of a firm in a year, $C L$ is the amount of current liabilities of a firm in a year and TotAs is the amount of assets of a firm in a year.

The square term of the financial leverage is computed as:

$$
\text { SqFinLev } v_{i, t}=\text { FinLev } v_{i, t}^{2}
$$

\section{Control variables}

The control variable for the size of a company (Size) is constructed as a natural logarithm of the amount of assets:

$$
\operatorname{Size}_{i, t}=\ln T \text { ot } A s_{i, t}
$$

HereTotAs is the amount of assets of a firm in a year. 
To control the results for the influence ofthe value-generating intangible assets the variable of tangibility (Tang)is added. It is measured as the ratio of fixed assets to total assets:

$$
\operatorname{Tang}_{\mathrm{i}, \mathrm{t}}=\frac{F L A s_{i, t}}{\operatorname{Tot}_{\mathrm{N}} s_{\mathrm{i}, \mathrm{t}}}
$$

Here FixAs is the amount of fixed assets of a firm in a year and TotAs is the amount of assets of a firm in a year.

As a control for growth opportunities rather than level of growth capital expenditure variable (CapEx) is added to the models. It is calculated as a natural logarithm of company's capital expenditures:

CapEx $x_{i, t}=\ln$ CapExpenditures $_{i, t}$

Here CapExpenditures ${ }_{t}$ is the amount of capital expenditures of a firm in a year.

The control variable for profitability (Prof) is calculated as a share of operating profit in total assets:

$$
\operatorname{Prof}_{\mathrm{i}_{2} \mathrm{t}}=\frac{\overline{E B I T D A_{i, t}}}{{\operatorname{Tot} A s_{i, \mathrm{t}}}_{\mathrm{s}}}
$$

Here EBITDA is the amount of operating profit of a firm in a year and TotAs is the amount of assets of a firm in a year.

\section{Data}

The sample used for the research contains public companies from chemical industry financial information for which were taken from 1998 till 2017 from the Thomson Reuters database. The database provides filter for choosing only chemical public companies. And it originally offered information about 1797 companies. However, after deleting companies with missing data in one or several variables there are only 1019 companies left. The final sample consists of 12945 firm-year observations.

Descriptive statistics of the dependent and independent variables for the future regression analysis can be seen in table 2 below. 
Table 2. Descriptive statistics of variables.

\begin{tabular}{|c|c|c|c|c|c|}
\hline Variable & Min & Max & Average & $\begin{array}{c}\text { St. } \\
\text { deviation }\end{array}$ & Median \\
\hline $\mathrm{Q}$ & 0.102 & 13.423 & 1.471 & 1.075 & 1.147 \\
\hline Flev & 0.011 & 2.817 & 0.499 & 0.206 & 0.504 \\
\hline SqFLev & 0.000 & 7.933 & 0.292 & 0.245 & 0.254 \\
\hline Size & 13.458 & 25.203 & 19.379 & 1.824 & 19.334 \\
\hline Tang & 0.002 & 0.990 & 0.478 & 0.171 & 0.479 \\
\hline CapEx & 0.000 & 22.831 & 15.949 & 2.552 & 16.125 \\
\hline Prof & -1.004 & 0.767 & 0.102 & 0.081 & 0.097 \\
\hline Gr & 0.005 & 28.044 & 1.213 & 4.064 & 1.052 \\
\hline $\mathrm{Z}$ & 0.001 & 36.230 & 4.118 & 3.755 & 2.943 \\
\hline $\mathrm{Zg}$ & 0 & 1 & 0.303 & 0.46 & 0 \\
\hline $\mathrm{Zs}$ & 0 & 1 & 0.49 & 0.5 & 0 \\
\hline
\end{tabular}

Source: authors' sample

Tobin's q varies from 0.1 to more than 13 with an average of 1.5 which means that in chemical industry the value of company differs from company to company in yes of investors just like in other industries, though, generally companies are valued for more than their assets. Financial leverage is also very different among chemical companies though the average level of 0.5 suggests that companies actively use both ways of financing their activities.

Tangibility (the share of fixed assets in total assets) varies from almost zero to almost one which is remarkable. This suggests that some chemical companies don't use any fixed assets and, perhaps, only trade in chemicals while other companies almost do not have any intangibles or at least do not count their reputation and research and development knowledge as part of their assets.

Growth rate and $\mathrm{Z}$ Altman score also vary quite much. This means that sample contain companies of both high growth and low growth and financially healthy and unhealthy companies. The average rates of growth and Altman's safe zone dummy, however, imply that chemical industry in general is growing but not fast and is quite healthy financially.

\section{Research results and their interpretation}

The method chosen for testing hypotheses is regressions based on ordinary least square method. The non-correlation of independent variables (except for the pair of the financial leverage and the square term of the financial leverage) is shown in table 3. 
Table 3. Correlation matrix of independent variables.

\begin{tabular}{|c|c|c|c|c|c|c|c|c|}
\hline & Flev & SqFLev & Size & Tang & CapEx & Prof & Gr & Z \\
\hline Flev & 1 & & & & & & & \\
\hline SqFLev & 0.92 & 1 & & & & & & \\
\hline Size & 0.28 & 0.21 & 1 & & & & & \\
\hline Tang & 0.08 & 0.07 & 0.25 & 1 & & & & \\
\hline CapEx & 0.23 & 0.15 & 0.30 & 0.23 & 1 & & & \\
\hline Prof & -0.10 & -0.12 & 0.08 & -0.06 & 0.17 & 1 & & \\
\hline Gr & 0.03 & 0.02 & 0.01 & 0.02 & 0.00 & -0.01 & 1 & \\
\hline Z & -0.13 & -0.11 & -0.19 & -0.19 & -0.13 & 0.21 & 0.00 & 1 \\
\hline
\end{tabular}

Source: authors' sample

The big statistical correlation between the financial leverage and its square term is purely mathematical. The slight correlation between the size and the financial leverage of the firm is probably due to the fact that bigger firms can afford to have higher amounts of debt without that much risk of bankruptcy. And the slightly bigger correlation between the size and capital expenditures is the result of the need of big companies to maintain their production capacities and invest in new areas to keep in line with competitors.

To estimate regressions' coefficients two models were used. First one was a fixed effects model as it is shown to fit best by different tests (Wald test, Hausman test, BreuschPagan test). Second one was pooled ordinary least squares estimations with instrumental variables for financial leverage to avoid endogenity problem. The instrumental variables used are one year lagged financial leverage, non-debt tax shields and corporate tax rate. The results of testing the instruments validity can be seen in Appendix 2.

The results from two methods of estimation are slightly different. The models estimated by fixed effects specification do not fit very well according to adjusted $\mathrm{R}$ squared and the coefficients crucial for testing of second and third hypotheses are statistically insignificant. The results of fixed effects model can be seen in Appendix 1.The models estimated by ordinary least squares method with instrumental variables fit much better and the results are statistically significant. Thus, these models are used to test the hypotheses.

The results for testing first two hypotheses can be seen in table 4 .

Table 4. Results of testing the first and second hypotheses.

\begin{tabular}{|c|c|c|c|c|}
\hline & \multicolumn{2}{|c|}{ H1 } & \multicolumn{2}{c|}{ H2 } \\
\hline & Coef & SE & Coef & SE \\
\hline flev & $0.237^{* * *}$ & 0.067 & $1.219^{* * *}$ & 0.16 \\
\hline sqflev & - & - & $-1.287^{* * *}$ & 0.217 \\
\hline size & $-0.062^{* * *}$ & 0.008 & $-0.062^{* * *}$ & 0.008 \\
\hline tang & -0.017 & 0.058 & -0.033 & 0.058 \\
\hline capex & $0.054 * * *$ & 0.006 & $0.062^{* * *}$ & 0.006 \\
\hline prof & $3.254 * * *$ & 0.234 & $3.265^{* * *}$ & 0.232 \\
\hline cons & $1.316^{* * *}$ & 0.095 & $1.54 * * *$ & 0.111 \\
\hline R2 & 0.29 & & 0.28 & \\
\hline Waldchi & 452.27 & & 456.91 & \\
\hline
\end{tabular}




\begin{tabular}{|c|c|c|c|c|}
\hline Probabity $>$ Chi & 0 & & 0 & \\
\hline Legend: $* \mathrm{p}<.1 ; * * \mathrm{p}<.05 ; * * * \mathrm{p}<.01$ &
\end{tabular}

Source: authors' calculation

On the whole, the regression for testing of first hypothesis is statistically significant. Both the financial leverage and three control variables (size, capital expenditures and profitability) have significant effect on Tobin's Q in the sample of chemical public companies.

The market value of a chemical company depends positively on its financial leverage (with coefficient of 0.237 ). Thus, it is possible to say that the more debt the company has the bigger economy on tax and the more discipline for top managers it gets. At the same time, as chemical companies normally have capital intensive production and, therefore, have a quite big liquidation value, the investors are not likely to worry about company's solvency when the leverage rises and still value company highly. Hence, bigger amounts of debt raise the value of a firm.

Also capital expenditures and profitability have a positive influence on value of a firm which makes sense as more profitable firms with bigger investments are likely to have higher value. Yet size has a negative influence on value. Thus, first hypothesis is not rejected.

Ton the whole, the regression for testing of second hypothesis is statistically significant. Financial leverage, its square term and three control variables (same as in first hypothesis) have significant influence on company's value.

The company's value continues to depend positively on its financial leverage (with coefficient of 1.219) but it depends negatively on squared financial leverage (with coefficient of -1.287). And relationship between company's Tobin's Q and financial leverage is concave. The optimal level of debt (in terms of maximizing company's value) is on average $47.36 \%$. So if the company goes beyond that level of debt its value might decrease.

It suggests that the square term of the financial leverage has some influence over the company's value for chemical firms. And high levels of debt have adverse effect on the way investors value a company. It means that when companies reach high levels of debt past the optimum suboptimal investment strategies might be triggered which are not compensated by all the management control and tax shield functions. Thus, second hypothesis is not rejected.

The results for testing third and fourth hypotheses can be seen in table 5 .

Table 5. Results of testing the third and fourth hypotheses.

\begin{tabular}{|c|c|c|c|c|}
\hline & \multicolumn{2}{|c|}{ H3 } & \multicolumn{2}{c|}{ H4 } \\
\hline & Coef & SE & Coef & SE \\
\hline flev & $0.248^{* * *}$ & 0.069 & $1.114^{* * *}$ & 0.225 \\
\hline gr & $0.009^{* *}$ & 0.004 & - & - \\
\hline flevgr & $0.008^{*}$ & 0.006 & - & - \\
\hline zg & - & - & $0.126^{*}$ & 0.154 \\
\hline zs & - & - & $0.673^{* * *}$ & 0.159 \\
\hline flevzg & - & - & $0.647^{* *}$ & 0.227 \\
\hline flevzs & - & - & $1.222^{* * *}$ & 0.245 \\
\hline
\end{tabular}




\begin{tabular}{|c|c|c|c|c|}
\hline size & $-0.063 * * *$ & 0.008 & $-0.063 * * *$ & 0.007 \\
\hline tang & -0.018 & 0.058 & $0.564 * * *$ & 0.053 \\
\hline capex & $0.054 * * *$ & 0.005 & $0.038 * * *$ & 0.004 \\
\hline prof & $3.261 * * *$ & 0.325 & $0.872 * * *$ & 0.202 \\
\hline _cons & 1.308 & 0.095 & $0.504 * * *$ & 0.158 \\
\hline R2 & 0.26 & & 0.59 & \\
\hline Waldchi & 456.69 & & 5115.78 & \\
\hline Probabity>Chi & 0 & & 0 & \\
\hline
\end{tabular}

Legend: * $\mathrm{p}<.1 ; * * \mathrm{p}<.05 ; * * * \mathrm{p}<.01$

Source: authors' calculation

The regression for testing of the third hypothesis is overall statistically significant. Coefficients before all the independent and most of control variables are significant. Control variables continue to have coefficients of the same signs and statistical significances in the models for testing first two hypotheses.

Coefficients before the financial leverage (0.248), growth rate (0.009) and their interaction term (0.008) are positive, even though the two last ones are not very high. This means that relation between the value and the leverage remains positive with newly added factor of growth and that growth of the company lightly strengthens this positive relation. For example, at $25 \%$ quartile of growth the marginal effect of the leverage on the value is 0.255 And at $75 \%$ quartile it goes up to 0.258 . This is a very little change. Thus, at $25 \%$ quartile of growth one standard deviation increase of leverage $(0.206)$ results in 0.061 increase in Tobin's q and 75\% quartile - in 0.064 increase. This is quite a small amount given that average Tobin's q for the sample is 1.47. Thus, third hypothesis is not rejected; yet growth does not seem to be a very important factor of the relationship between the financial leverage and the firm's value.

On the whole, the regression for testing of the fourth hypothesis is statistically significant. Coefficients before all the independent and control variables are significant. And R-squared of the model is 0.59.It means that the model is much better fit than previous models and its results describe the relationship between value and leverage of the company quite well.

Coefficients before the financial leverage (1.114), "grey zone" dummy (0.126), "safe zone" dummy (0.637) and their interaction terms (0.647 and 1.222 respectively) are positive. This means that relation between the value and the leverage remains positive with newly added factor of financial health and that financial health of the company strengthens this positive relation. For example, for companies that are in distress zone according to Altman's z-score the marginal effect of the leverage on the value is 1.114.For companies in grey zone it goes up to 1.761. And for companies in safe zone it is 2.336. Thus, for financially unhealthy companies one standard deviation increase of leverage (0.206) results in 0.229 increase in Tobin's q and for financially healthy companies - in 1.098 increase. The difference of 0.869 is quite a big amount given that average Tobin's q for the sample is 1.47 .

Capital expenditures and profitability continue to have a positive effect on firm value and size of company - negative as they did in models for testing previous hypotheses. Tangibility coefficient is also significant in this model unlike in all others meaning that investors prefer companies with more physical assets. Thus, fourth hypothesis is not rejected and financial health is a very important factor in investors pricing of chemical companies. 


\subsection{Test of financial crisis influence}

The financial crisis of 2008-2009 has changed some aspects of financial behavior of firms throughout the world (Demirguc-Kunt et. al. (2015); Iqbal,Kume (2014), Paunov (2012)). To check the effect of financial crisis of 2008-2009 on the influence of different factors on the relationship between the financial leverage and the firm's value the hypotheses were tested on two periods: before and after the crisis. Observations were divided into two groups: 3652 firm-year observations in 1998-2007 and 7646 firm-year observations in 2010-2017. Ordinary least squares method with instrumental variables is used to estimate the models. The results can be seen in Appendix 3.

Results of testing the first and fourth hypotheses are about the same for before and after crisis observations and are much alike but slightly better fitted than the results without the division of observations.

Results of testing the second hypothesis are statistically insignificant before crisis and significant after crisis. The model estimated on after crisis observations is alike the model estimated on the whole sample so it can be said that the general relationship between the leverage, its square term and the value for the whole sample is based mostly on the observations from the post-crisis period.

Results for testing the third hypothesis are statistically insignificant in before and after crisis models. The general model estimated for testing of the third hypothesis also had weak coefficients before growth related variables. Therefore, the third hypothesis is rejected on the whole.

Thus, the influence of leverage on value was about the same before and after the crisis. Yet before the crisis investors didn't care if the company had large amounts of debt while after the crisis big level of debt began to have adverse effects on the value of company.

Also in models estimated for all four hypotheses tangibility coefficient is statistically significant after crisis (but not before crisis or in models for the whole period) and profitability has much less influence after crisis than before it. So we can say that investors became more cautious in evaluating firms after crisis and started to relay more on the physical assets and amount of debt and less on profitability.

\section{Conclusion}

Raising value of a company is one of the most central goals for the business so it is important to observe and manage factors influencing it, especially the financial leverage. Previous works have shown that relation between the financial leverage and the company's value exists. However, they have not come to universal conclusion about the sign of such relation or the factors affecting it.

In this work the relation between the leverage and the value of a firm and factors influencing it were studied on a sample of public chemical companies. The relation itself is positive. Yet especially in the after crisis period the big amounts of debt influence company's market value negatively as shown by the influence of the square term of financial leverage on the market value. At the same time, financial stability influences the relation between the leverage and the value only partly. On the one hand, financial health strengthens the relation regardless the considered period. On the other hand, growth has little or no influence on the relation.

The study done in this work shows that for chemical companies the relation between the leverage and the value is positive. However, we have found two factors that affect it. Big 
levels of debt have the opposite - adverse - effect on the value of a company. While good financial health make the relationship stronger.

Thus, top management of a public chemical company that follows the strategy of increasing its market value can increase debt level of their company as long as they keep finances healthy and don't reach too high levels of leverage.

\section{References}

1. F. Modigliani, M. Miller, M., The cost of capital, corporation finance and the theory of finance. Amer. Ec. Rev., 48, no. 3, pp. 291-297 (1958)

2. F. Modigliani, M. Miller, M. Corporate income taxes and the cost of capital: A correction. Amer. Ec. Rev., 53, pp. 433-443 (1963)

3. S. Myers, Determinants of corporate borrowing. J. of Finan. Ec., 5, pp. 146-175 (1977)

4. S. Myers, N. Majluf, N., Corporate financing and investment decisions when firms have information that investors do not have. J. of Finan. Ec., no. 13, pp. 187-221 (1984)

5. A. Kraus, R. Litzenberger, R., A State-Preference Model of Optimal Financial Leverage. J. of Finan., no. 33, pp. 911-922 (1973)

6. McConnell, J., Servaes, H., "Equity ownership and the two faces of debt", Journal of Financial Economics, vol. 39, no. 1, p. 131-157 (1995)

7. R. Aggarwal, X. Zhao, X., The leverage-value relationship puzzle: An industry effects resolution. J. of Ec. and Bus., 59, no. 4, pp. 286-297 (2007)

8. P. De Andres Alonso, F. Iturriaga, J. Sanz, Financial decisions and growth opportunities: a Spanish firm's panel data analysis. Appl. Finan. Ec, 15, no. 6, pp. $391-407$ (2005)

9. M. Cheng, Z. Tzeng, The Effect of Leverage on Firm Value and how the firm financial quality influence on this effect. World J. of Manag., vol. 3, no .2, pp. $30-53$ (2011)

10. A. Adenugba, A. Ige, O. Kesinro, Financial Leverage And Firms' Value: A Study Of Selected Firms In Nigeria. Eur. J. of Res. and Ref. in Manag. Scie., 4, no. 1, pp. 14-32 (2016)

11. M. Farooq, A. Masood, Impact of Financial Leverage on Value of Firms: Evidence from Cement Sector of Pakistan. Res. J. of Fin. and Acc., 7, no. 9, pp. 73-77 (2016)

12. A. Khan, The relationship of capital structure decisions with firm performance: A study of the engineering sector of Pakistan. Intern. J. of Acc. and Finan. Report. 2, no. 1, p. 245-262 (2012)

13. M. Soumadi, O. Hayajneh, Capital Structure and corporate performance empirical study on the public Jordanian Shareholdings firms listed in the Amman Stock Market. Eur. Scie. J., 8, no. 22, pp. 173-189 (2012)

14. S. Fosu, Capital structure, product market competition and firm performance: Evidence from South Africa. The Quarterly Rev. of Ec. and Fin., 53, no. 2, pp. 140-151 (2013) 
15. S. Fosu, S. Danso, A. Ahmad, W. Coffie, Information Asymmetry, Leverage and Firm Value: Do Crisis and Growth Matter? Intern. Rev. of Finan. Analysis, no. 46, pp. 140-150 (2016)

16. M. Soumadi, Hayajneh, Capital Structure and corporate performance empirical study on the public Jordanian Shareholdings firms listed in the Amman Stock Market. Eur. Scie. J., 8, no. 22, pp. 173-189 (2012)

17. J. Cai, Z. Zhang, Leverage Change, Debt Overhang, and Stock Prices. J. of Corp. Finan., 17, no. 3, pp. 391-402 (2011)

18. M. Ishari, S. Abeyrathna, The Impact of Financial Leverage on Firms' Value (Special Reference to Listed Manufacturing Companies in Sri Lanka)”. Intern. J. Of Advan. In Eng. Tech., Manag. and Appl. Scie., vol. 3, no. 7, p. 100-104 (2016)

19. A. Barakat, The Impact of Financial Structure, Financial Leverage and Profitability on Industrial Companies Shares Value (Applied Study on a Sample of Saudi Industrial Companies). Res. J. of Finan. and Acc., 5, no. 1, pp. 55-66. (2014)

20. S. Fosu, A. Danso, W. Ahmad, W. Coffie, Information Asymmetry, Leverage and Firm Value: Do Crisis and Growth Matter? Intern. Rev. of Finan. Anal., no. 46, pp. 140150 (2016)

\section{Appendices}

Appendix 1. Results of testing hypotheses with fixed effects specification of OLS

Results of testing the first and second hypotheses

\begin{tabular}{|c|c|c|c|c|}
\hline & \multicolumn{2}{|c|}{ H1 } & \multicolumn{2}{c|}{ H2 } \\
\hline & Coef & SE & Coef & SE \\
\hline flev & $0.691 * * *$ & 0.064 & $0.632^{* * *}$ & 0.137 \\
\hline sqflev & - & - & 0.048 & 0.101 \\
\hline size & $0.247^{* * *}$ & 0.015 & $0.247^{* * *}$ & 0.015 \\
\hline tang & $0.294 * * *$ & 0.079 & $0.291 * * *$ & 0.079 \\
\hline capex & 0.002 & 0.005 & 0.002 & 0.005 \\
\hline prof & $3.079 * * *$ & 0.128 & $3.081^{* * *}$ & 0.127 \\
\hline cons & $5.715^{* * *}$ & 0.281 & $5.725703^{* * *}$ & 0.281 \\
\hline R2 & 0.08 & & 0.08 & \\
\hline F statistics & 13.12 & & 13.1 & \\
\hline Probabity>F & 0 & & 0 & \\
\hline
\end{tabular}

Legend: * $\mathrm{p}<.1 ; * * \mathrm{p}<.05 ; * * * \mathrm{p}<.01$

Source: authors' calculation 
Results of testing the third and fourth hypotheses

\begin{tabular}{|c|c|c|c|c|}
\hline & \multicolumn{2}{|c|}{ H3 } & \multicolumn{2}{c|}{ H4 } \\
\hline & Coef & SE & Coef & SE \\
\hline flev & $0.691^{* * *}$ & 0.064 & $1.138^{* * *}$ & 0.101 \\
\hline gr & 0.001 & 0.007 & - & - \\
\hline flevgr & -0.002 & 0.01 & - & - \\
\hline zg & - & - & $0.039^{*}$ & 0.08 \\
\hline zs & - & - & $0.432^{* * *}$ & 0.075 \\
\hline flevzg & - & - & $0.326^{* *}$ & 0.126 \\
\hline flevzs & - & - & $1.018^{* * *}$ & 0.121 \\
\hline size & $0.247^{* * *}$ & 0.015 & $-0.177^{* * *}$ & 0.014 \\
\hline tang & $0.294^{* * *}$ & 0.079 & $-0.024 * *$ & 0.075 \\
\hline capex & 0.002 & 0.005 & -0.002 & 0.005 \\
\hline prof & $3.078^{* * *}$ & 0.128 & $1.96 * * *$ & 0.124 \\
\hline cons & $5.715^{* * *}$ & 0.281 & $3.706^{* * * *}$ & 0.276 \\
\hline R2 & 0.08 & & 0.19 & \\
\hline F statistics & 13.11 & & 17.16 & \\
\hline Probabity>F & 0 & & 0 & \\
\hline
\end{tabular}

Legend: * $\mathrm{p}<.1 ; * * \mathrm{p}<.05 ; * * * \mathrm{p}<.01$

Source: authors' calculation

\section{Appendix 2. Results of testing the validity of instrumental variables}

Results of testing relevance of instruments

\begin{tabular}{|l|l|l|l|l|l|}
\hline \multicolumn{1}{|l|}{ First-stage regression summary statistics } \\
\hline Variable & R-sq. & $\begin{array}{l}\text { Adjusted } \\
\text { R-sq. }\end{array}$ & $\begin{array}{l}\text { Partial R- } \\
\text { sq. }\end{array}$ & F(0,12936) & Prob>F \\
\hline flev & 0.2767 & 0.2762 & 0.3651 & 764.84 & 0 \\
\hline Minimumeigenvaluestatistic $=764.84$ & \multicolumn{5}{l|}{} \\
\hline CriticalValues & $5 \%$ & $10 \%$ & $20 \%$ & $30 \%$ \\
\hline Ho: Instrumentsareweak & 13.91 & 9.08 & 6.46 & 5.39 \\
\hline & $10 \%$ & $15 \%$ & $20 \%$ & $25 \%$ \\
\hline 2SLS relative bias & 22.30 & 12.38 & 9.54 & 7.80 \\
\hline & 6.46 & 4.36 & 3.69 & 3.32 \\
\hline 2SLS Size of nominal 5\% Wald test & & & & 3 \\
\hline LIML Size of nominal 5\% Wald test & \# ofexcludedinstruments: & 3 \\
\hline
\end{tabular}

Conclusion: instruments are not weak. 
Results of testing exogenity of instruments

\begin{tabular}{|l|}
\hline Testofoveridentifyingrestrictions: \\
\hline Score chi2 2$)=4.256(\mathrm{p}=0.1763)$ \\
\hline
\end{tabular}

Conclusion: instruments are exogeneous.

Appendix 3. Results of testing hypotheses in periods before and after financial crisis of 2008-2009

Results of testing the first hypothesis

\begin{tabular}{|c|c|c|c|c|}
\hline & \multicolumn{2}{|c|}{ Before crisis } & \multicolumn{2}{c|}{ After crisis } \\
\hline & Coef & SE & Coef & SE \\
\hline flev & $0.35^{* * *}$ & 0.126 & $0.297 * * *$ & 0.109 \\
\hline size & $-0.102^{* * *}$ & 0.014 & $-0.091^{* * *}$ & 0.012 \\
\hline tang & -0.102 & 0.105 & $-0.262^{* * *}$ & 0.075 \\
\hline capex & $0.055^{* * *}$ & 0.009 & $0.072^{* * *}$ & 0.01 \\
\hline prof & $4.415^{* * *}$ & 0.244 & $2.97 * * *$ & 0.158 \\
\hline cons & $1.947^{* * *}$ & 0.2 & $1.833^{* * *}$ & 0.138 \\
\hline R2 & 0.38 & & 0.27 & \\
\hline Waldchi & 419.02 & & 520.5 & \\
\hline Probabity>Chi & 0 & & 0 & \\
\hline
\end{tabular}

Legend: $* \mathrm{p}<.1 ; * * \mathrm{p}<.05 ; * * * \mathrm{p}<.01$

Source: authors' calculation

Results of testing the secondhypothesis

\begin{tabular}{|c|c|c|c|c|}
\hline & \multicolumn{2}{|c|}{ Before crisis } & \multicolumn{2}{c|}{ After crisis } \\
\hline & Coef & SE & Coef & SE \\
\hline flev & 0.023 & 1.419 & $0.696^{*}$ & 0.306 \\
\hline sqflev & -0.568 & 1.274 & $-0.836^{* *}$ & 0.259 \\
\hline size & $-0.102^{* * *}$ & 0.014 & $-0.089^{* * *}$ & 0.012 \\
\hline tang & -0.112 & 0.108 & $-0.267^{* * *}$ & 0.075 \\
\hline capex & $0.058^{* * *}$ & 0.01 & $0.077^{* * *}$ & 0.01 \\
\hline prof & $4.443^{* * *}$ & 0.244 & $2.996^{* * *}$ & 0.156 \\
\hline cons & 2.048 & 0.278 & $0.148^{* * *}$ & 0.148 \\
\hline R2 & 0.35 & & 0.25 & \\
\hline Waldchi & 429.08 & & 568.93 & \\
\hline Probabity>Chi & 0 & & 0 & \\
\hline
\end{tabular}

Legend: $* \mathrm{p}<.1 ; * * \mathrm{p}<.05 ; * * * \mathrm{p}<.01$

Source: authors' calculation 
Results of testing the thirdhypothesis

\begin{tabular}{|c|c|c|c|c|}
\hline & \multicolumn{2}{|c|}{ Before crisis } & \multicolumn{2}{c|}{ After crisis } \\
\hline & Coef & SE & Coef & SE \\
\hline flev & $0.821^{*}$ & 0.459 & $0.319^{*}$ & 0.083 \\
\hline gr & 0.226 & 0.203 & 0.009 & 0.027 \\
\hline flevgr & -0.352 & 0.332 & -0.011 & 0.034 \\
\hline size & $-0.104 * * *$ & 0.015 & $-0.092^{* * *}$ & 0.013 \\
\hline tang & -0.1 & 0.106 & $-0.262^{* * *}$ & 0.075 \\
\hline capex & $0.055^{* * *}$ & 0.009 & $0.072^{* * *}$ & 0.009 \\
\hline prof & $4.403^{* * *}$ & 0.242 & $2.974^{* * *}$ & 0.159 \\
\hline cons & $1.713^{* *}$ & 0.29 & $1.823^{* * *}$ & 0.142 \\
\hline R2 & 0.37 & & 0.27 & \\
\hline Waldchi & 430.86 & & 522.49 & \\
\hline Probabity>Chi & 0 & & 0 & \\
\hline
\end{tabular}

Legend: * $\mathrm{p}<.1 ; * * \mathrm{p}<.05 ; * * * \mathrm{p}<.01$

Source: authors' calculation

Results of testing the fourthhypothesis

\begin{tabular}{|l|l|l|l|l|}
\hline & \multicolumn{2}{|c|}{ Before crisis } & \multicolumn{2}{c|}{ After crisis } \\
\hline & \multicolumn{1}{|c|}{ Coef } & \multicolumn{1}{c|}{ SE } & \multicolumn{1}{c|}{ Coef } & \multicolumn{1}{c|}{ SE } \\
\hline flev & $1.114^{* * *}$ & 0.374 & $1.326^{* * *}$ & 0.314 \\
\hline zg & $0.016^{*}$ & 0.009 & $0.059^{*}$ & 0.036 \\
\hline zs & $0.534^{* * *}$ & 0.197 & $0.874^{* * *}$ & 0.186 \\
\hline flevzg & $0.469^{* *}$ & 0.189 & $0.52^{* * *}$ & 0.271 \\
\hline flevzs & $1.147^{* * *}$ & 0.379 & $1.035^{* * *}$ & 0.317 \\
\hline size & $-0.091^{* * *}$ & 0.013 & $-0.063^{* * *}$ & 0.011 \\
\hline tang & $0.548^{* * *}$ & 0.099 & $0.358^{* * *}$ & 0.072 \\
\hline capex & $0.038^{* * *}$ & 0.008 & $0.043^{* * *}$ & 0.008 \\
\hline prof & $1.797 * * *$ & 0.233 & $1.027 * * *$ & 0.144 \\
\hline cons & $0.967 * * *$ & 0.389 & $0.397^{* * *}$ & 0.086 \\
\hline R2 & 0.61 & & 0.6 & \\
\hline Waldchi & 1498.01 & & 2749.37 & \\
\hline Probabity>Chi & 0 & & 0 & \\
\hline
\end{tabular}

Legend: * $\mathrm{p}<.1 ; * * \mathrm{p}<.05 ; * * * \mathrm{p}<.01$

Source: authors' calculation 